\title{
The effect of the establishment and application of European law in Poland - selected theoretical issues
}

Keywords: European law, application of law, multi-central order, friendly interpretation, Poland

\begin{abstract}
The article is focused on the effect of the establishment and application the European Union law in Poland immediately after 2004. By becoming the law binding in Poland (and other member states of the EU), the EU law effected significant changes in the sphere of law creation and application. Traditionally, in the national legal order, the law of the highest force is the constitution, while in accordance with the EU legal order, the regulations of the European law are superior in their application in the territory of the member states, including the regulations of the constitution. The present analysis explains how the dilemma of the simultaneous superiority of the regulations of the constitution and the regulations of the EU law was solved in Poland and what importance is attributed to the concept of favourable interpretation of the national law and the EU law. The present paper poses the hypothesis that the model of reconciling the regulations of the Polish law and the regulations of the European law developed in Poland immediately after 2004 was correctly established. It contributes well to Poland meeting international obligations, at the same time respecting the superior position of the constitution.
\end{abstract}

The fact of belonging to the European Union gives rise to a constitutional problem for each of the member states referring to the relations between the national law and the EU law. This issue is connected with the openness of the

* ORCID ID: https://orcid.org/0000-0002-8231-4454, Associate Professor at the Faculty of Political Science and International Studies, University of Warsaw, Poland. 
national order to the European law and the following constitutional doubts concerning guarantees of sovereignty and realization of the political power by the Nation as the sovereign of the political power in the state. In contemporary times the legal order in Europe is for the states belonging to the EU a multi-component and multi-central order. It comprises treaty norms and those which are established by the EU institutions as well as those which are created within the national order. At the same time, it is a dynamic system. Relations between the EU and national orders undergo evolution accompanied by changes taking place above all in the EU law, and - within a narrower scope - also in the national law.

Therefore, it is logical that both the state's accession to the EU itself and particular further changes in the procedures of establishing the EU law cause a reaction of the member states in the form of initiating control over compat- ibility with the national constitution. The relation between the Union law and the national law is a mechanism where, on the other hand, the bodies of the member state participate (in various forms and stages) in forming the content of the future EU law and, on the other hand, are independent national law-makers ${ }^{1}$. Hence, on the European level, on the one hand, and in the national order, on the other, competence basis, mechanisms and procedures are created which secure participation in the establishment of the EU law and, at the same time, create guarantees of preserving the desired balance between the formation of relations by law on the levels of the EU and the law established in the country ${ }^{2}$. Each change in the EU mechanism, therefore, requires checking the system of mechanisms and guarantees in the national law remaining in correlation with the former. Controlling constitutionality ensures this very verification, which is confirmed by the practice of European constitutional tribunals and courts, including the Polish one. In Poland the Treaty of accession was successfully tested for its constitutionality 3 and so was the Lisbon Treaty, which - among other things - made changes in the scope of the mechanism of the establishment of the Union law, both primary and secondary ${ }^{4}$.

1 Broadly on the effect of the Polish membership in EU on the process of establishing the law, see: J. Jaskiernia, Wpływ integracji z Unią Europejska na funkcję ustawodawcza Sejmu, «Studia Prawnicze» 2006, No. 3.

${ }^{2}$ On the effectiveness of the parliament's influence on the establishment of the EU law, see:

J. Jaskiernia, Członkostwo Polski w Unii Europejskiej a problem efektywnościoddziaływania parlamentu narodowego na proces tworzenia prawa w UE, [in:] M. Marczewska-Rytko (ed.), Polska w strukturach Unii Europejskiej: Doświadczenia - oczekiwania - wyzwania, Lublin 2010.

3 The decision of the Constitutional Court from 11 May 2005, file reference K 18/04, Z.U. 49/5/A/2005.

${ }^{4}$ The decision of the Constitutional Court from 24 November 2010, file reference K 32/09, Z.U. 108/9/A/2010. 
In the constitution of the Republic of Poland from 2 April 1997 the parliament decided that the system of law binding in the territory of the Republic of Poland would be of multi-component character, including acts of international law and - indirectly - also the EU law, in addition to the laws established by the Polish legislative bodies. Through being directly anchored in the regulations of the Constitution of the Republic of Poland, the EU law is not the law fully external towards the Polish State. The law of treaties is established by accepting the treaties concluded by all member states (including the Republic of Poland). On the other hand, the EU law is created with the participation of the governments of the member states (including Poland) in the Council and representatives of European citizens (including the Polish citizens) in the European Parliament. The Polish legislator had to determine - within the constitutional limits - the rules according to which the Polish government would shape its standpoint in European matters in its cooperation with the Sejm and the Senate 5 .

Hence, sub-systems of legal regulations co-exist in Poland and they come from different law-making centres. They should co-exist in accordance with the mutually friendly interpretation and common application ${ }^{6}$. This fact shows another perspective of a potential collision of norms and the superiority of one of the distinguished sub-systems. The assumption of a multi-component structure of the system of law binding in Poland is of general character. As a result of the regulations included in art. 9, art. 87, item 1 and art. 90-91, the Constitution recognizes this multi-component structure of norms binding in the territory of the Republic of Poland and provides for a special procedure of implementing it. This procedure shows similarity to the procedure of changing the Constitution. Emphasis on the superior position of the Constitution cannot threaten the uniform binding of the EU law and the harmonious execution of the duties of Poland as a member state. However, within the scope included within the conferral the Republic of Poland allows for the establishment of legal acts binding in the Polish territory or binding Poland in exterior relations according to the rules determined in the Treaty of Lisbon.

The Polish constitutional law-maker (National Assembly) takes the standpoint of the unity of the legal system regardless of whether the legal acts making up this system are the effect of the national legislator or they were established as

5 Broadly on his subject, in: R. Balicki, Udział Rady Ministrów w tworzeniu prawa europejskiego, [in:] M. Jabłoński, S. Jarosz-Żukowska (eds.), Zasada pierwszeństwa prawa Unii Europejskiej w praktyce działania organów władzy publicznej RP, Wrocław 2015.

6 The decision of the Constitutional Court from 11 May 2005, file reference K 18/04, Z.U. 49/5/A/2005. Broadly on his subject, in: A. Sołtys, Obowiazek wyktadni prawa krajowego zgodnie z prawem unijnym jako instrument zapewniania efektywności prawa Unii Europejskiej, Warszawa 2015. 
international regulations (of different scopes and character) included within the constitutional catalogue of the sources of law. In accordance with art. 91 item 1 of the Constitution, a ratified international agreement, after promulgation in the Journal of Laws of the Republic of Poland, constitutes part of the legal order of the Republic of Poland. It is also applied directly (unless its application depends on the enactment of a statute). On the other hand, international agreements provided for in art. 90 item 1 of the Constitution on delegation to an international organization or international institution of certain competences of organs of state authority in relation to "certain matters" are one of the categories of international agreements subject to ratification. Ratification of such an agreement takes place in accordance with the procedure of clearly tightened requirements in comparison to the procedure of ratification of other agreements carried out after previous consent of the Sejm and the Senate provided for in the law ${ }^{7}$. This tightened procedure consists of raising the threshold of the necessary majority in the Sejm and the Senate from the level of ordinary majority to a two-thirds majority vote in the Sejm and the Senate, or - alternatively (by virtue of the statute of the Sejm passed by an absolute majority of votes) - granting consent for ratification in a nationwide referendum. It is just basing on such an international agreement ratified by the president of the Republic of Poland with the consent of the nation expressed in a referendum that Poland became a member of the EU.

Art. 91 item 2 of the Constitution the Polish parliament guaranteed precedence of the application of international agreements ratified upon prior consent granted by statute or by a nationwide referendum (in accordance with art. 90 item 3 ), including precedence of agreements on delegation of the competences in relation to "certain matters" over the provisions of statutes which cannot be coapplied. Analogous precedence of those agreements over the provisions of the Constitution cannot be derived from this precedence. Therefore, the Constitution remains - due to its special force - "the supreme law of the Republic of Poland" in relation to all international agreements binding Poland. This also refers to ratified international agreements on delegation of the competences in relation to "certain matters" or the regulations of the EU law. Due to the superiority of the legal force on the Constitution following from art. 8 item 1 of the Constitution, the latter has precedence of its binding force and application on the territory of the Republic of Poland.

When Poland acquired membership in the European Union in 2004, it was automatically bound by the primary and secondary law of the Union. It became a component of the Polish law subject to direct application in the territory of

${ }^{7}$ Cf. J. Jaskiernia, Projekt klauzuli integracyjnej do Konstytucji RP, «Państwo i Prawo» 2011, No. 1, p. 9. 
Poland and causing the direct effect ${ }^{8}$. That is why the law applying bodies are expected to interpret internal law in accordance with the European law 9 . This causes that even the legal norms of the EU law which in themselves are not fit for direct application constitute the point of reference and the obligatory criterion to achieve accordant interpretation. Moreover, it is considered an obligation to use the European law as a model in interpreting internal law. Since the moment Poland joined the European union it has been obliged to observe the rules of interpretation following from acquis communautaire. This also refers to the meth- ods of interpretation applied in the jurisdiction of Polish courts as well as the Constitutional Court. In case there should be a few possibilities of interpretation, the one which is closes to acquis communautaire should be chosen, which was stated by the Court of Justice of the European Union in the case of Marleasing SA $v$ La Comercial Internacional de Alimentacion $S A^{10}$ and which does not raise any doubts in the Polish doctrine of law.

From the point of view of the creation of political, social or economic relations, the proper reception of European law is the process not to be ignored. Together with the advancing process of integration, the EU law becomes - in quantitative and qualitative aspects - the segment of law binding in each member state. For example, it is estimated that in the field of economic policy about $60 \%$ of regulations binding in Poland are not the ones that were created in the Sejm but in the EU bodies. At the same time, it should be emphasized that EU affects the shape of legal systems of member states practically without any par-ticipations of their parliaments. This lack of participation of national legislative bodies refers above all to the stage of establishing the Union law, which is also binding to the national parliaments.

The very concept and model of the European law created a new situation where autonomous legal orders are binding side by side ${ }^{11}$. Their interaction cannot be fully described by means of a traditional scheme: internal law - international

${ }^{8}$ Cf. D. Kabat-Rudnicka, Konstytucjonalizacja Unii Europejskiej a sądownictwo konstytucyjne. Wielopoziomowa wspótpraca czy rywalizacja?, Warszawa 2016, p. 190; A. Kalisz, Wykładnia i stosowanie prawa wspólnotowego, Warszawa 2007, pp. 41 ff.; A. Trubalski, Prawne aspekty implementacji prawa UE do systemu prawnego RP, Warszawa 2016, pp. $15 \mathrm{ff}$.

${ }^{9}$ M. Gołda-Sobczak, Wykładnia proeuropejska w orzecznictwie Trybunatu Konstytucyjnego, [in:] K. Urbaniak (ed.), Skarga konstytucyjna. Zagadnienia teorii i praktyki, Poznań 2015, p. 283.

10 The decision of the Court of Justice of the European Union from 13 November 1990 concerning the case C-106/89, Marleasing SA vs La Comercial Internacional de Alimentacion SA, 1 ECR 4135 1990, pp. I-4135.

${ }^{11}$ More on EU law as an autonomous order, see: T. Jaroszyński, Rozporządzenie Unii Europejskiej jako składnik systemu prawa obowiazujacego w Polsce, Warszawa 2011, pp. $62 \mathrm{ff}$. 
law. The occurrence of relative autonomy of legal orders based on their own internal hierarchical rules does not mean a lack of mutual effect. It does not also eliminate the possibility of a collision between the regulations of the EU law and constitutional provisions. It occurs when there is an irremovable contradic- tion between the norm of the constitution and the norm of the EU law and this contradiction cannot be removed applying the interpretation respecting the relative autonomy of the European law and the domestic law. Such a situation cannot be excluded but - due to the assumed common domestic and Union assumptions and values - it can occur but exceptionally.

Such a contradiction cannot be solved in the Polish law by recognizing the superiority of the Union norm in relation towards the constitutional one. It also cannot lead to the loss of the binding force of the constitutional norm, which would be replaced by the Union norm. Nor can it lead to the limitation of the range of the application of this norm to the area which was not included within the regulation of the Union law. In such a situation the Polish legislator's task is to make the decision either on changing the Constitution or effecting changes in the Union regulations, or - as the last resort - the decision to leave the European Union. This decision should be made by the sovereign, which is the Polish Nation or the body of the state power which can represent the Nation in agreement with the Constitution. The norms of the Constitution in the field of individual rights and freedoms mark the intransgressible threshold which cannot be lowered or questioned as a consequence of the implementation of the Union regulations. In this sphere, the Constitution has the role of a guarantee from the point of view of the protection of freedoms and rights established in it in relation to all enti- ties subject to the Polish law. The interpretation "friendly to the European law" in connection with the principle of loyal cooperation (placing an obligation on the member states of the EU to undertake all necessary measures with the aim to realize the obligations following from the Union legal order ${ }^{12}$ ) has its limits. In no situation can it lead to the results contradicting the distinct wording of the constitutional norms and impossible to be settled with the minimum of the guaranteeing function realized by the Constitution ${ }^{13}$. Therefore, there is no possibility of questioning the binding force of the constitutional norm through the very fact of introducing a community regulation to the system of the European law contradicting the latter.

12 M. Laskowska, M. Taborowski, Obowiazek wykładni przyjaznej prawu Unii Europejskiej - między otwartościa na proces integracji a ochrona tożsamości konstytucyjnej, [in:]

S. Dudzik, N. Półtorak (eds.), Prawo Unii Europejskiej a prawo konstytucyjne państw czlonkowskich, Warszawa 2013, p. 84.

${ }^{13}$ The decision of the Constitutional Court from 11 May 2005file reference K 18/04, Z.U. 49/5/A/2005. 
The rule of superiority of the EU law towards domestic law is strongly exposed by the jurisdiction of the Court of Justice of EU. This situation is justified by the objectives of European integration and the needs to create a common European legal space. This principle is certainly an expression of the pursuit to guarantee uniform application and execution of the European law. Nevertheless, it does not determine the final decisions undertaken by the member states in the conditions of a collision between a Union regulation and a constitutional regulation. In the Polish system of law decisions of this type should be always made considering the content of art. 8 item 1 of the Constitution. According to it, the Constitution is the supreme law of the Republic of Poland.

The Constitution of the Republic of Poland and the EU law are based on the same set of common values determining the nature of a democratic state of law and a catalogue and content of basic laws. In accordance with art 6 item 1 TEU:

The Union is founded on the principles of liberty, democracy, respect for human rights and fundamental freedoms, and the rule of law, principles which are common to the member states.

The consequence of the axiology of the legal systems common for all the states ${ }^{14}$ is also the fact that the rights guaranteed in the European Convention for the Protection of Human Rights and Fundamental Freedoms from 1950 and those following from the constitutional traditions common to the member states create in accordance with art. 6 item 2 TEU - the general principles of EU law. This fact significantly faciliates the co-application and the mutually friendly internpretation of the national and EU law since it minimizes the risk of axiological tensions. The dialogue of national bodies, the Court of Justice and the European court of Human Rights has significant importance in the shaping of the European legal space ${ }^{15}$.

The main, but not the only, depositary of competences in the field of the application of treaties in the legal system of the European Union is the Court of Justice of the European Union. It decrees on the validity and interpretation of the Community law. The interpretation of the Community law made by CJEU should be placed within the functions and competences transferred by the member states to the EU. It should also correlate with the rule of subsidiarity, determining the work of the Union institutions. Besides, this interpretation should be based on the assumption of mutual loyalty between the Union institutions and the member states. On the part of CJEU, this assumption generates an obligation of favour

\footnotetext{
${ }^{14}$ A. Kalisz, Stosowanie i wyktadnia prawa Unii Europejskiej, [in:] W. Dziedziak, B. Liżewski (eds.), Zagadnienia stosowania prawa. Perspektywa teoretyczna i dogmatyczna, Lublin 2015, p. 191.

${ }^{15}$ A. Sołtys, Obowiązek wykładni zgodnej w orzecznictwie Trybunału Konstytucyjnego (cz. II), «Europejski Przegląd Sądowy» 2014, May, p. 16.
} 
to the national systems of law, and - on the part of the member states - an obligation of the highest standard to respecting the Union regulations. The member states keep the right to assess whether the legislative Union bodies which issued definite regulations of law acted within the frameworks of the conferred competences and whether they executed their competences in accordance with the principles of subsidiarity and proportionality. Trespassing those frameworks causes that the issued regulations are not included within the rule of superiority of the EU law.

National courts have the duty to directly apply the norms of domestic law. However, the judge in a given country is also obliged to examine whether the given actual state is subject to the norms of the EU regulation directly applied in the territory of each member state ${ }^{16}$. In accordance with art. 9 of the Constitution, Poland respects international law binding upon it, which also refers to the autonomous, though genetically based on international law, legal system of EU law. On the other hand, according to art. 10 of TEC, Member States take all appropriate measures, whether general or particular, to ensure fulfilment of the obligations arising out of this Treaty or resulting from action taken by the institutions of the Community. They facilitate the achievement of the Community's tasks. In relation to the bodies of the judiciary, the manner of realizing this general obligation to observe international and Community law is specified by the collision norm from art. 91 item 2 of the Constitution. Hence, the national courts also have the right and obligation to refuse to apply the domestic norm if it collides with the EU law norms. In such a situation the national court does not decree on the annulment of the norm of domestic law but it only refuses to apply it within the scope it is obliged to give precedence to the EU law norm. The said act of law is not severable; it is binding and is applied in the scope not included in the substantive and temporal force of the EU regulation. In case of doubts concerning the relation of the domestic norm and the EU norm, it is necessary to refer a prejudicial question to ECJ as the competent body in matters of interpretation of the Treaty and the norms of derivative law, and in the functional sense thus included in the judicial system of a given member state.

The European Court of Justice guards the Community law, while the Constitutional Court guards the Constitution. A collision might arise here between the settlements of the Constitutional Court and the Court of Justice. In view of the above, it should be stated that also considering the content of art. 8 item 1 of the Constitution, the Constitutional Court has an obligation to view its posi- tion in such a way that in essential matters, concerning the political dimension,

16 See the decision of ECJ from 19 May 1990 in the case The Queen vs Secretary of State for Transport/ ex parte Factortame Ltd. and others, 213/98. 
it keeps the position of the "court of the last word" in reference to the Polish Constitution. The Court of Justice and the Constitutional Court cannot be placed as competitive courts towards each other. It is not only about eliminating the phenomenon of overlapping of both courts or duplication in the field of decreeing on the same legal issues but also dysfunctionality in the relations of the EU and Polish legal orders. It is crucial to consider the indicated difference of the roles of both Courts ${ }^{17}$.

The Constitutional Court is competent to examine the compliance of the laws of derivative Community law with the Constitution ${ }^{18}$. In doing so, it should remember that the EU law is binding in all member states of the Union. One of the political principles of the Community law is the principle of loyal cooperation. In accordance with art. 4 item 3 of TEU, the Union and the Member States shall, in full mutual respect, assist each other in carrying out tasks which follow from the Treaties. They take any appropriate measure, general or particular, to ensure fulfillment of the obligations arising out of the Treaties or resulting from the acts of the institutions of the Union. The Member States facilitate the achievement of the Union's tasks and refrain from any measure which could jeopardise the attainment of the Union's objectives. Granting particular states the competences to decide on the deprivation of the binding force of the EU norms would be difficult to comply with this principle. On the other hand, the idea of art. 4 item 2 of TEU is that the Union respects the national identities of its member states, inherent in their fundamental, political and constitutional structures ${ }^{19}$.

Attention should be paid to different ways of avoiding the state of incompatibility of the EU law with the Constitution. The status of the supreme law of the Republic of Poland was guaranteed to the Constitution ${ }^{20}$. This regulation is accompanied by the order to respect and favour the properly shaped regulations of international law binding in the territory of the Republic of Poland (art. 9 of the

17 The decision of the Constitutional Court from 19 December 2006, file reference P 37/05, ZU No. 11/A/2006, item 177.

${ }^{18}$ Broadly on his subject, in: A. Chmielarz, Kontrola konstytucyjności prawa pochodnego Unii Europejskiej, «Przegląd Sejmowy»2012, No. 4; M. Jabłoński, S. Jarosz-Żukowska, Kontrola konstytucyjności prawa pochodnego UE w trybie skargi konstytucyjnej i pytań prawnych, [in:] M. Jabłoński, S. Jarosz-Żukowska (eds.), Zasada pierwszeństwa prawa Unii Europejskiej w praktyce działania organów władzy publicznej RP, Wrocław 2015;

M. Laskowska, Dopuszczalność kontroli zgodności aktów pochodnego prawa UE z Konstytucja RP. W przeddzień rozstrzygnięcia Trybunału Konstytucyjnego, «Studia Prawnicze KUL» 2011, No. 2.

${ }^{19}$ For example, the decision from 22 December 2010 in the case C-208/09 Sayn-Wittgenstein, and the decision from 12 May 2011 in the case C- 391/09 Runevič-Vardyn.

${ }^{20}$ B. Banaszak, Zasada nadrzędności Konstytucji w polskim porzadku prawnym, [in:]

M. Jabłoński, S. Jarosz-Żukowska (eds.), Zasada pierwszeństwa prawa Unii Europej- skiej w praktyce działania organów władzy publicznej RP, Wrocław 2015, p. 51. 
Constitution). In the sentence concerning the Accession Treaty, the Constitutional Court emphasized that the sub-systems of legal regulations coming from different law-making centers should co-exist according to the principle of mutually friendly interpretation and cooperative co-application. Any contradictions should be eliminated by using the interpretation respecting the relative autonomy of the European and national systems of law. Moreover, this interpretation should be based on mutual loyalty between the EU institutions and the member states. On the part of the Court of Justice, this assumption generates an obligation of favour towards the national legal systems, while on the part of the member states - an obligation of the highest standard in respecting the EU norms. In addition, control over the compatibility of an EU regulation with the Constitution exercised by the Constitutional Court should be treated as independent but also subsidiary towards the judicial competences of the Court of Justice of the European Union. Joining the European Union, the Republic of Poland delegated to the European Union the competences of the organs of state authority in certain matters (art. 90 item 1 of the Constitution). This also includes delegation of competences to establish law. Consequently, legal acts created by the institutions of the European Union are binding in Poland. In accordance with the principle of conferral (art. 5 item 1 of TEU), which is fundamental to the law of the European union, the Union's competences, including the law-making ones, can be realized only within the limits adopted by the member states in treaties. Besides, the Republic of Poland accepted the division of functions concerning control over the acts of law ${ }^{21}$. The result of this division of functions is assigning to the Court of Justice of the European Union the competences for the ultimate interpretation of the EU law and the assurance of its application in all member state as well as the exclusive right to decree on the compatibility of the acts of derivative law with the trea- ties and general principles of the EU law. It is in this context that the subsidiary character of competences of the Constitutional Court should be viewed to examine the compatibility of the EU law with the Constitution. Before decreeing on the incompatibility of an act of derivative law with the Constitution, the content of the norms of the EU derivative law which is the subject of control should be examined. This can be done by raising a prejudicial question to the Court of Justice on the basis of art. 267 of TFEU on interpretation or validity of the regulations which raise doubts 22 . Following the decision of the Court of Justice, it may turn out that the content of the questioned EU norm is compatible with the Constitu-

21 The decision of the Constitutional Court from 18 February 2009, file reference Kp 3/08, OTK ZU No. 2/A/2009 item 9.

${ }^{22}$ An analogous opinion was expressed by the German Federal Constitutional Court in its judgment from 6 July 2010 in Honeywell case, file reference 2 BvR 2661/06. 
tion. Another possibility is that the Court of Justice will decree on the incompatibility of the challenged sentence with the EU primary law. In the situations presented above, decisions by the Constitutional Court would be superfluous. Although both courts have different scopes of jurisdiction, due to the similarities of values expressed in the Constitution and the treaties, there is high likelihood that the assessment of the Court of Justice will be similar to the assessment of the Constitutional Court.

The consequences of the judgment of the Constitutional Court in case of decreeing incompatibility of the norms of the EU derivative law with the Constitution should be considered. In the case of the Polish law acts, such a consequence is the loss of the binding force of the normative acts incompatible with the Constitution (art. 190 items 1 and 3 of the Constitution). This kind of consequence is impossible in reference to the acts of the EU derivative law since the binding force of such acts is not determined by the Polish bodies. The consequence of the judgment of the Constitutional Court would only be depriving the acts of the EU derivative law of the possibility to be used by the Polish organs and produce legal effects in Poland. The consequence of the judgment of the Constitutional Court is, therefore, suspending the application of the norms of the EU law incompat-ible with the Constitution in the territory of the Republic of Poland. It should be noticed that such a consequence of the judgment of the Court would be difficult to reconcile the duties of a member state and the aforementioned principle of loyal cooperation (art. 4 item 3 TEU). The consequence of the discussed state of affairs could be the proceedings against Poland by the European Commission and a complaint brought to the Court of Justice against Poland for infringing its obligations following from the treaties (art. 258-260 TFEU). The judgment on the incompatibility of the EU law with the Constitution should without any doubt have the character of ultima ratio and occur only should all other ways of solving the conflict with the norms belonging to the UE legal order fail. In situations of this kind it should be accepted that after the Constitutional Court decided on the incompatibility of definite norms of the EU derivative law with the Constitution, actions should be immediately undertaken to remove this state. The Constitutional principle of a favourable attitude to the European integration and the treaty principle of loyalty of the member states towards the Union require that the consequences of the Court's judgment should be delayed in accordance with art. 190 item 3 of the Constitution.

In conclusion, immediately after 2004, both the Polish law and the EU law have developed sets of mechanisms of coordination and co-application of the Polish and the EU systems of law, which lowers the probability of conflicts in this sphere and in case they appear, it allows their elimination. 


\section{Bibliography}

R. Balicki, Udział Rady Ministrów w tworzeniu prawa europejskiego, [in:] M. Jabłoński, S. Jarosz-Żukowska (eds.), Zasada pierwszeństwa prawa Unii Europejskiej w praktyce działania organów władzy publicznej RP, Wrocław 2015.

B. Banaszak, Zasada nadrzędności Konstytucji w polskim porządku prawnym, [in:] M. Jabłoński, S. Jarosz-Żukowska (eds.), Zasada pierwszeństwa prawa Unii Europejskiej w praktyce działania organów władzy publicznej RP, Wrocław 2015.

A. Chmielarz, Kontrola konstytucyjności prawa pochodnego Unii Europejskiej, «Przegląd Sejmowy» 2012, No. 4.

M. Gołda-Sobczak, Wykładnia proeuropejska w orzecznictwie Trybunatu Konstytucyjnego, [in:] K. Urbaniak (ed.), Skarga konstytucyjna. Zagadnienia teorii i praktyki, Poznań 2015.

M. Jabłoński, S. Jarosz-Żukowska, Kontrola konstytucyjności prawa pochodnego UE $w$ trybie skargi konstytucyjnej i pytań prawnych, [in:] M. Jabłoński, S. Jarosz-Żukowska (eds.), Zasada pierwszeństwa prawa Unii Europejskiej w praktyce działania organów władzy publicznej RP, Wrocław 2015.

T. Jaroszyński, Rozporządzenie Unii Europejskiej jako składnik systemu prawa obowiazującego w Polsce, Warszawa 2011.

J. Jaskiernia, Członkostwo Polski w Unii Europejskiej a problem efektywności oddziaływania parlamentu narodowego na proces tworzenia prawa w UE, [in:] M. Marczewska-Rytko (ed.), Polska w strukturach Unii Europejskiej: Doświadczenia - oczekiwania - wyzwania, Lublin 2010.

J. Jaskiernia, Projekt klauzuli integracyjnej do Konstytucji RP, «Państwo i Prawo» 2011, No. 1.

J. Jaskiernia, Wpływ integracji z Unią Europejska na funkcję ustawodawcza Sejmu, «Studia Prawnicze» 2006, No. 3.

D. Kabat-Rudnicka, Konstytucjonalizacja Unii Europejskiej a sądownictwo konstytucyjne. Wielopoziomowa wspótpraca czy rywalizacja?, Warszawa 2016.

A. Kalisz, Stosowanie i wykładnia prawa Unii Europejskiej, [in:] W. Dziedziak, B. Liżewski (eds.), Zagadnienia stosowania prawa. Perspektywa teoretyczna i dogmatyczna, Lublin 2015.

A. Kalisz, Wyktadnia i stosowanie prawa wspólnotowego, Warszawa 2007.

M. Laskowska, Dopuszczalność kontroli zgodności aktów pochodnego prawa UE z Konstytucją RP. W przeddzień rozstrzygnięcia Trybunatu Konstytucyjnego, «Studia Prawnicze KUL» 2011, No. 2.

M. Laskowska, M. Taborowski, Obowiązek wykładni przyjaznej prawu Unii Europejskiej - między otwartościa na proces integracji a ochrona tożsamości konstytucyjnej, [in:] S. Dudzik, N. Półtorak (eds.), Prawo Unii Europejskiej a prawo konstytucyjne państw członkowskich, Warszawa 2013.

A. Sołtys, Obowiazek wykładni prawa krajowego zgodnie z prawem unijnym jako instrument zapewniania efektywności prawa Unii Europejskiej, Warszawa 2015.

A. Sołtys, Obowiąek wykładni zgodnej w orzecznictwie Trybunału Konstytucyjnego (cz. II), «Europejski Przegląd Sądowy» 2014, May.

A. Trubalski, Prawne aspekty implementacji prawa UE do systemu prawnego RP, Warszawa 2016. 